\title{
POLITIK PENDIDIKAN KARAKTER: Refleksi Praksis Pendidikan Karakter di Indonesia
}

\author{
Sjamsi Pasandaran
}

Dosen Jurusan Pendidikan Pancasila dan Kewarganegaraan FIS UNIMA

\begin{abstract}
Abstrak
Pendidikan karakter merupakan salah satu agenda penting bagi bangsa Indonesia, bahkan jauh sebelum Indonesia merdeka. Melalui pemikiran Ki Hajar Dewantara tercermin pentingnya karakter menjadi ruh pendidikan, menjadi pilar-pilar karakter bangsa yang harus dibentuk melalui pendidikan. Bahkan ketika di awal-awal kemerdekaan Indonesia para pendiri negara (the founding father) mengagendakan Nation and Character building sebagai salah satu agenda yang menjadi tantangan bagi bangsa Indonesia yang merdeka. Hal itu nampak dalam berbagai pidato politik Soekarno, dan melihat masalah karakter sebagai salah satu masalah pembangunan bangsa yang sangat penting. Terdapat kebutuhan pembentukan karakter yang sangat penting di awal kehidupan Indonesia merdeka dari suatu tatanan kehidupan penjajahan ke suatu tatanan kehidupan bangsa yang merdeka. Dibutuhkan suatu ciri karakter masyarakat dan bangsa yang siap membangun dan mengisi kemerdekaan.
\end{abstract}

Kata Kunci: Politik, Pendidikan, Pendidikan Karakter

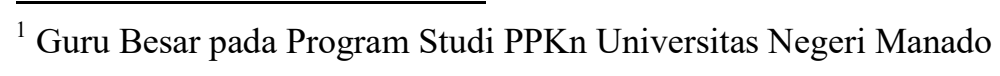




\section{Pendahuluan}

Pendidikan karakter merupakan salah satu agenda penting bagi bangsa Indonesia, bahkan jauh sebelum Indonesia merdeka. Melalui pemikiran Ki Hajar Dewantara tercermin pentingnya karakter menjadi ruh pendidikan, menjadi pilar-pilar karakter bangsa yang harus dibentuk melalui pendidikan. Bahkan ketika di awal-awal kemerdekaan Indonesia para pendiri negara (the founding father) mengagendakan Nation and Character building sebagai salah satu agenda yang menjadi tantangan bagi bangsa Indonesia yang merdeka. Hal itu nampak dalam berbagai pidato politik Soekarno, dan melihat masalah karakter sebagai salah satu masalah pembangunan bangsa yang sangat penting. Terdapat kebutuhan pembentukan karakter yang sangat penting di awal kehidupan Indonesia merdeka dari suatu tatanan kehidupan penjajahan ke suatu tatanan kehidupan bangsa yang merdeka. Dibutuhkan suatu ciri karakter masyarakat dan bangsa yang siap membangun dan mengisi kemerdekaan.

Di sepanjang sejarah ppendidikan sesudah Indonesia merdeka, dan dalam satu decade terakhir, pembangunan karakter tetap menjadi agenda pembangunan nasional yang sangat penting bagi Indonesia. Urgensi tersebut terkait dengan tantangan-tantangan yang dihadapi oleh Bangsa Indonesia baik masalah temporer saat ini maupun tantangan di masa depan. Pertama tantangan untuk membangun masyarakat yang harmonis di tengah-tengah keragaman (harmony in diversity). Indonesia adalah masyarakat yang sangat pluralis baik karena agama, suku bangsa, adat istiadat, maupun bahasa. Dalam konteks kehidupan pluralistic diperlukan kompetensi keragaman cultural (cultural diversity competence) yaitu suatu kompetensi yang mencakaup pemahaman tentang keragaman budaya, sikap dan kemampuan menghargai keragaman dan membangun lkehidupan bersama dalam keragaman itu.

Kedua, tantangan penyiapan generasi emas menyongsong seratus tahun Indonesia merdeka tahun 2045. Saat ini terdapat satu generasi muda usia 0 - 9 tahun, dan $10-19$ tahun yang berjumlah kurang lebih 84.000 juta. Pada tahun 2045, mereka akan menjadipenduduk usia produktif dan mengambil peran sebagai pemimpin bangsa pada semua lapis dan bidang kehidupan baik politik, pemerintahan, ekonomi, social, militer, maupun pendidikan dan budaya. Mereka sudah harus disiapkan untuk memiliki karakter yang baik dan menjadi warganegara yang cerdas (civic intelligence), warganegara yang bertanggungjawab (civic responsibility) dan warganegara yang partisipatif (civic participation). Memiliki keterampilan hidup, inovatif dan kreatif serta memiliki kemampuan literasi teknologi informasi dan komunikasi.

Ketiga, tantangan globalisasi dan kemajuan teknologi terutama teknologi informasi dan komunikasi. Globalisasi dan kemajuan teknologi informasi dan komunikasi TIK) disadari membawa dampak baik positif maupun negative. Globalisasi dan kemajuan TIK akan menghadirkan sistem nilai baru, tatanan kehidupan interdependensi, kompetitif,menguatnya interkoneksi, dan semakin meningkatnya tuntutan akan kualitas dan produktivitas. Kondisi-kondisi dan kebutuhan-kebutuhan tersebut berimplikasi pada tuntutan akan sikap, watak dan perilaku adaptif, responsive sehingga seseorang itu mampu menghadapi hidup dan mengembangkan karir, mengembangkan semua potensi diri dan berinteraksi dengan lingkungannya tanpa tercabut dari akar budaya. 
Keempat, Indonesia saat ini menghadapi permasalahan karakter bangsa. Terdapat gejala-gejala yang memprihatinkan yang mengindikasikan permasalahan karakter yang serius, yaitu: (1) disorientasi dan belum dihayatinya nilai-nilai Pancasila, (2) keterbatasan perangkat kebijakan terpadu dalam mewujudkan nilai-nilai Pancasila, (3) bergesernya nilai etika dalam kehidupan berbangsa dan bernegara, (4) memudarnya kesadaran terhadap nilai-nilai budaya bangsa, (5) ancaman disintegrasi bangsa, dan (6) melemahnya kemandirian bangsa. (Winataputra, 2010). Sebagai bangsa kita telah memiliki sistem nilai budaya yang terkristalisasi di dalam nilai-nilai Pancasila. Pancasila telah disepakati bersama menjadi filosofi dan pandangan hidup bangsa, menjadi dasar kehidupan berbangsa, bernegara dan bermasyarakat, dan juga menjadi ideology dalam kehidupan bernegara. Namun penghayatan dan pengamalan nilai-nilai Pancasila semakin melemah dan bahkan menunjukkan kecenderungan melemahkan kedudukan dan peran Pancasila. Gejala yang menunjukkan melemahnya etika kehidupan berbangsa dan bernegara sangat nampak pada fenomenafenomena budaya kekerasan yang terjadi di mana-mana, budaya koruspi yang menjadi ordinary crime atau kejahatan luar biasa dan bahkan sudah sangat membahayakan. Data mengenai Indeks Persepsi Korupsi tahun 2013 menunjukkan Indonesia berada pada posisi 114 dari 175 negara di dunia. Posisi tersebut masih berada di bawah posisi negara-negara ASEAN seperti Singapore menempati posisi 5 dunia, Brunei Darussalam berada pada peringkat 38 dunia, Malaysia menampati peringkat 53 dunia, Philipines pada posisi 94 dunia dan Thailand pada peringkat 102 dunia. (Corruption
Perception Index. https://www.transparency.org/cpi2014).

Kondisi-kondisi tersebut sudah sangat mengkuatirkan karena menenmpatkan Indonesia menjadi salah satu negara terancam gagal. Thomas Lickona, mengemukakan beberapa gejala yang dapat mengindikasikan menurunnya moral dan karakter sebagai ancaman bagi suatu negara menuju kehancuran yaitu (1) violence and vandalism, (2) stealing, (3) Cheating, (4) disrespect for authority, (5) Peer cruelty, (6) bigotry, (7) bad language, (8) sexual precocity and abuse, (9) increasing selfcenteredness and declining civic responsibility, (10) self-destructive behavior (Lickona, 1992:123-18). Gejala-gejala yang dikemukakan oleh Thomas Lickona tersebut teramati sebagai suatu gejala umum dalam kehidupan sehari-hari. Budaya kekerasan, penggunaan bahasa yang buruk, tindakan kejahatan, pelecehan seskual, melemahnya rasa hormat terhadap symbol-simbol negara, korupsi menjadi perilaku yang membudaya, menguatnya primordialisme kelompok yang mengarah pada radikalisme dan fundamentalisme, melemahnya kohesi social merupakan kecenderungan-kecenderung yang menunjukkan fenomena melemahnya karakter di masyarakat.

Pendidikan karakter menjadi sangat sentral bagi banyak negara dalam memperkuat pembangunan karakter suatu bangsa. Semua negara bersama pemerintahan masing-masing memiliki kebijakan mengenai pembangunan karakter melalui pendidikan karakter. Kebijakan tersebut memiliki perbedaan latar belakang baik karena pandangan ideologis, sosiologis, kutlural maupun politik negara dan pemerintah. Praxis pendididkan karakter pun berbeda sesuai dengan tujuan yang ingin dicapai. Sekalipun terdapat nilai-nilai 
universal yang ingin dicapai melalui pendidikan karakter tetapi kepentingan politik, pemerintahan, ideologis dan sosiokultural menyebabkan terdapat perbedaan dalam praksis pendidikan karakter. Setiap negara juga memiliki landasan empiric yang berbeda, tergantung pada kondisi dan realitas permasalahan pembangunan karakter suatu bangsa. Bagaimana pemikiran dan praxis pendidikan karakter di suatu negara akan mencerminkan politik pendidikan karakter di negara itu. Makalah ini secara khusus akan mengkaji masalah-masalah berikut ini:

1. Konsep tentang pendidikan karakter itu dan politik pendidikan karakter?

2. Aspek konstitusionalitas dan yuridis pendidikan karakter di Indonesia

3. Aspek historis pendidikan karakter di Indonesia

\section{Konsepsi Pendidikan Karakter dan Politik Pendidikan Karakter}

\section{a) Karakter dan Pendidikan Karakter}

Berbicara mengenai politik pendidikan karakter, tidak dapat dilepaskan dari persepsi mengenai pendidikan karakter. Setiap orang, termasuk orang tua memiliki persepsi tentang karakter yang baik dan berdasarkan persepsi tersebut orang tua memberikan pendidikan karakter bagi anak-anaknya. Orang tua yang berpendidikan rendah pun memiliki persepsi mengenai apa yang baik, yang harus diajarkan kepada anak-anaknya sebagai sikap dan perilaku yang baik yang harus dimiliki dan yang harus dilakukan oleh anak-anaknya. Setiap masyarakat dan komunitas pun memiliki persepsi mengenai karakter yang baik, tergantung pada sistem nilai yang dimiliki sebagai sistem nilai bersama suatu komunitas. Hal ini akan sangat jelas dalam kehidupan masyarakat dengan sistem adat istiadat dan kesukuan yang masih kuat. Terdapat suatu sistem nilai yang harus diwariskan kepada anak-anak dengan cara yang berbeda dari satu komunitas atau masyarakat dengan komunitas atau masyarakat lainnya. Dalam lingkup yang lebih luas, setiap bangsa dan negara memiliki preferensi nilai mengenai nilai-nilai sebagai ciri karakter yang baik yang harus dimiliki oleh setiap warga negara. Setiap negara memiliki sistem nilai bersama yang menjadi identitas diri, filosofi, dan pandangan hidup bersama. Setiap negara dan bangsa pun mempunyai kewajiban untuk membangun karakter bangsa, karakter masyarakat, dan bahkan karakter individu untuk menjadi suatu bangsa yang berkarakter kuat. Misalnya disiplin, jujur, peduli, bertanggungjawab merupakan ciri-ciri karakter yang harus dibangun oleh setiap pemerintahan negara dalam membangun suatu bangsa dan negara yang berkarakter kuat. Upaya-upaya yang dilakukan untuk membangun karakter yang kuat akan menjadi ciri politik pendidikan karakter setiap orang, setiap masyarakat, dan bahkan setiap negara.

Pendidikan karakter menjadi sangat penting dalam membangun suatu masyarakat, bangsa dan negara untuk menjadi masyarakat, bangsa dan negara yang berkarakter baik dan kuat. Membangun suatu masyarakat dan negara yang kuat, tidak cukup dengan mengembangkan kemampuan berpikir tanpa karakter. Marthin Luther King $\mathrm{Jr}$, pernah berkata bahwa We must remember that intelligence is not enough, Intelligence plus character. That is the goal of true education. Oleh sebab itu setiap upaya pendidikan harus terkandung di dalamnya upaya untuk membentuk karakter yang baik, dan karakter hanya dapat dibentuk melalui proses interaksi edukatif. Karakter harus dibentuk, dan tugas pendidikan ialah menjadi media atau jalan (race) dalam proses pembentukan karakter. 
Berbicara tentang pendidikan karakter, memerlukan pemahaman tentang karakter itu sendiri. Pemahaman tentang karakter akan memberi landasan dan perspektif tentang pendidikan karakter. Thomas Lickona mengemukakan definisi mengenai karakter sebagai berikut:

Character consists of ... values in action. Character . . . has three interrelated parts: moral knowing, moral feeling, and moral behavior. Good character consists of knowing the good, desiring the good, and doing the good-habits of the mind, habits of the heart, and habits of action. We want our children ... to judge what is right, care deeply about what is right, and then do what they believe to be right - even in the face of pressure from without and temptation from within. (Lickona, 1992:123-18.)

Definisi yang dikemukakan oleh Thomas Lickona tersebut menggambarkan bahwa berbicara tentang karakter berarti berbicara tentang nilai yang terlihat dalam tindakan seseorang. Tidak cukup seseorang mengetahui mengenai nilai tetapi juga harus nampak dalam keinginan untuk berbuat baik dan melakukan apa yang baik itu. Oleh sebab itu, ukuran seseorang memiliki karakter yang baik selalu dilihat dalam tiga hal yaitu mengetahui yang baik atau knowing the good, mencintai dan suka yang baik atau desiring the good, dan melakukan yang baik atau doing the good. Bahkan ketiga aspek tersebut harus menjadi kebiasaan atau habit yaitu kebiasaan untuk selalu berpikir mengenai hal-hal baik atau selalu berpikir positif (habits of the mind), kebiasan untuk mengingini atau menyukai yang baik (habits of the heart), dan kebiasaan untuk selalu melakukan yang baik atau habits of action. Setiap orang tua, guru, dan mungkin juga setiap orang mengingini agar anaknya mengetahui dan dalam menilai yang yang benar, peduli dengan hal-hal yang benar, dan melakukan apa yang mereka percayai sebagai sesuatu yang benar. Searah dengan pemikiran yang dikemukakan oleh Thomas Lickona tersebut, Lauree Beth Stedje, mendefinisikan karakter sebagai berikut:

Character is the culmination of habits, resulting from the ethical choices, behaviors, and attitudes an individual makes, and is the "moral excellence" an individual exhibits when no one is watching. It includes an individual's desire to do one's best, concern for others' wellbeing, cognition of critical thinking and moral reasoning, and the development of interpersonal and emotional skills that allow individuals the capability to work effectively with each other in everyday situations. (Stedje, 2010).

Karakter akan selalu tergambar dalam kebiasaan baik berpikir, bersikap, maupun bertindak. Mengajari seorang anak untuk mengetahui apa yang benar dan apa yang baik, dan bahkan menilai apa yang baik dan benar tidaklah terlalu sulit. Tetapi kesulitan mulai dialami ketika hendak menunbuhkan dan mengembangkan sikap kepedulian seorang anak terhadap hal-hal yang baik dan benar. Tidak cukup seorang anak mampu menilai apa yang baik dan mana yang benar. Tetapi harus juga diikuti dengan sikap yang terlihat dalam kepedulian terhadap hal-hal yang baik dan benar, dan kepedulian itu dinyatakan dalam bentuk tindakan yaitu melakukan apa yang dinilai baik dan benar. Ketiga aspek tersebut perlu secara terus menerus dilakukan sehingga menjadi suatu kebiasaan atau habits. Artinya sikap dan perilaku baik dan benar terebut tumbuh dari dorongan internal karena telah menjadi watak dan karakter.

Berdasarkan pemikiran-pemikiran tersebut di atas, maka dapat dikatakan bahwa 
karakter memiliki tiga aspek penting yaitu aspek kognitif, afektif, dan perilaku. Karakter akan selalu menunjukkan pengetahuan dan pemahaman seseorang terhadap apa yang baik dan benar. Pengetahuan dan pemahaman tersebut menjadi dasar dalam melakukan penilaian apa yang baik dan benar. Karakter juga menunjuk pada sikap positif seseorang terhadap apa yang dnilai baik dan benar. Sikap ini akan mendorong action tendency seseorang untuk bertindak atau berbuat baik dan benar. Melalui proses pembiasaan sikap dan perilaku tersebut akan menjadi ciri dan sifat karakter seseorang. Konsistensi dalam sikap dan perilaku menjadi unsur yang sangat penting untuk dapat menggambarkan sifat karakter seseorang. Seseorang yang secara konsisten tekun, disiplin, bertanggungjawab, dan correct dalam mengerjakan suatu pekerjaan akan memberi gambaran sifat karakter orang itu sebagai seseorang yang tekun, rajin, disiplin, bertanggungjawab, dan yang selalu bertindak tepat dan benar. Karakter merupakan kesatuan utuh yang menggambarkan aspek baik kongitif, afektif, maupun perilaku. Kesatuan utuh tersebut digambarkan dalam gambar 1 .

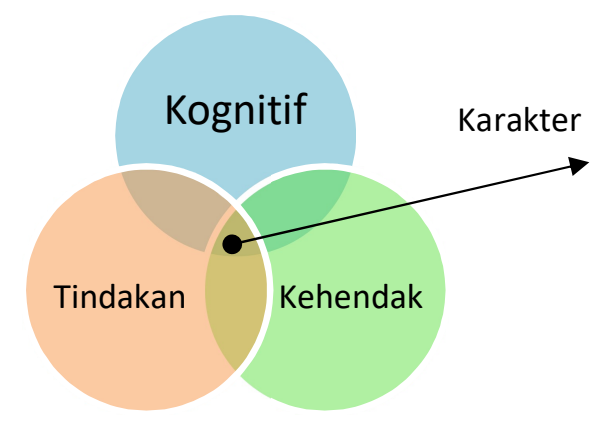

Gambar 1. Domain karakter

\section{b) Konsep Pendidikan Karakter}

Pendidikan karakter akan selalu menunjuk pada proses yaitu proses menanamkan, membentuk, dan mengembangkan nilai sehingga seorang anak mengetahui apa yang baik dan benar, menumbuhkan keinginan di dalam diri anak itu untuk melakukan apa yang baik dan benar, dan melakukannya dalam bentuk tindakan atau perilaku baik dan benar. Secara tradisional ketika di dalam keluarga, anak diajari dan dibiasakan untuk bersikap dan berbuat baik, maka didalam keluarga dimulai proses pendidikan karakter. Proses itu akan terus berlangsung ketika anak memasuki dan belajar di sekolah. Secara formal, anak akan mendapatkan pendidikan karakter baik melalui mata pelajaran maupun melalui berbagai kegiatan di sekolah. Di rumah anak akan belajar melalui proses pembiasaan (habituation) bagaimana bersikap dan berperilaku etik. Pembiasaan itu akan berkembang dan menjadi semakin kuat jika di sekolah anak mengalami proses yang sama. Problem akan muncul ketika di dua lingkungan ini yaitu lingkungan keluarga dan sekolah tidak saling mendukung, akan mengakibatkan anak mengalami konflik nilai dalam proses pembentukan karakternya.

Sebagai suatu proses menanamkan, membentuk, dan mengembangkan sikap dan perilaku etis, maka dapat dikatakan bahwa pendidikan karakter adalah suatu proses humanisasi yaitu sebagai suatu proses pemanusiaan. Pendidikan karakter menjadi suatu keharusan bagi seorang anak karena sangat terkait dengan pertimbangan moral, motivasi moral dan perilaku moral anak. Pertimbangan moral, dan sikap moral yang melandasi perilaku moral seseorang menggambarkan sifat karakternya. Lauree Beth Stedje menyebut fungsi pendidikan karakter adalah sebagai moral guide. Pendidikan karakter akan memberi landasan bagi seseroang untuk memberi pertimbangan moral mengenai apa yang baik dan benar 
secara moral. Pertimbangan moral itu akan menjadi landasan yang mendorong seseorang bersikap terhadap sesuatu, dan sekaligus mendorong seseorang bertindak atau tidak bertindak. Pendidikan karakter, dengan demikian mencakup tiga aspek utama yaitu mencakup aspek kognitif, afeksi, dan behavior atau perilaku. Pendidikan karakter berfungsi membentuk pengetahuan anak mengenai apa yang secara moral baik dan benar, membentuk sikap yang berisi konasi atau kehendak untuk melakukan sesuatu yang baik, dan aspek perilaku yaitu melakukan sesuatu yang baik dan benar.

Pemikiran Ki Hadjar Dewantara mengenai pendidikan sebagai proses humanisasi mencerminkan pemikiran beliau mengenai pendidikan karakter dan sekaligus kedudukan pendidikan karakter di dalam keseluruhan proses pendidikan. Pendidikan sebagai suatu proses humanisasi menunjukkan bahwa pendidikan karakter adalah esensial dalam pendidikan. Setiap proses pendidikan adalah proses membentuk karakter sehingga terjadi proses pemanusiaan manusia. Di dalam proses itu terdapat tiga aspek yang hendak dibentuk yaitu aspek kognitif yang mencakup pengetahuan, aspek konasi yang mencakup kehendak, dan aspek perilaku atau tindakan. Dengan demikian pendidikan karakter tidak cukup hanya memberikan pengetahukan tentang hal-hal yang baik dan benar atau pengetahuan tentang nilai kepada anak. Pendidikan karakter harus juga mencakup upaya-upaya yang mendorong anak ingin atau mencintai sesuatu yang baik dan mencintai nilai. Bahkan pendidikan karakter adalah proses pendidikan yang membentuk perilaku etik anak. Ketiga aspek tersebut merupakan satu kesatuan dan digambarkan sebagai berikut:

Gambar 2. Aspek-aspek Pendidikan Karakter

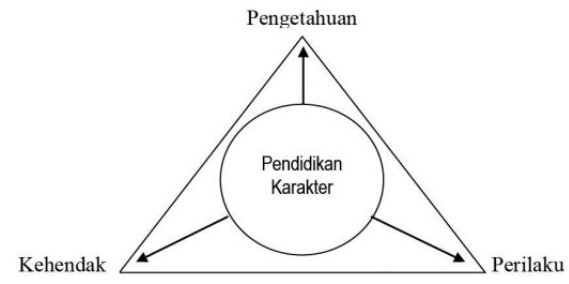

Oleh sebab itu para ahli seperti Howard dan Berkowitz mengemukakan bahwa fungsi pendidikan karakter adalah untuk mempersiapkan anak-anak untuk memiliki landasan etik sebagai pertimbangan moral dalam pengambilan suatu keputusan dan tindakan. Howard dan Berkowitz merumuskan fungsi dan peran pendidikan karakter sebagai berikut:

Character education is an attempt to prepare individuals to make ethical judgments and to act on them, that is, to do what one thinks ought to be done. ... Character education, a vital tool for preparing our young people in our schools, has had to confront political issues and challenges of its own. (Howard, dkk. 2004:189).

Dilihat dari fungsinya tersebut, maka penekanan utama dari pendidikan karakter adalah pada pembentukan sikap dan perilaku etik sebagai warganegara yang baik. Dalam konteks fungsi tersebut, Howard dan Berkowitz mengemukakan tiga pendekatan dalam pendidikan karakter yaitu the cognitive-developmental approach, the caring approach, and traditional character education. (Westheimer, dan Kahne, 2014). Pendekatan kognitif menekankan pada pentingnya pembentukan kemampuan knowing the good. Aspek kognitif secara gradual dapat mencakup kemampuankemampuan seperti mengetahui, memahami, mengaplikasi, menganalisis, berikir kritis dalam melakukan penilaian mengenai apa yang baik dan benar. Pendekatan kedua adalah pendekatan yang menekankan pada 
pembentukan kemamuan sikap seperti sikap peduli, empati, toleran. Pendekatan ketiga menekankan pada pembentukan perilaku etik sebagai sesuatu yang fundamental dalam pendidikan karakter. Di dalam praktik, ketiga pendekatan ini seyogianya dilaksana secara terintegrasi. Hal ini sangat penting, mengingat praktik pendidikan karakter selama ini lebih bersifat kognitif yaitu mengajarkan kepada anak pengetahuan tentang nilai, pengetahuan tentang nilai-nilai yang terkandung di dalam Pancasila, pengetahuan agama, dan pegnetahuan tentang ajaran moralitas.

\section{c) Politik Pendidikan Karakter di Indonesia}

Politik pendidikan karakter suatu negara akan selalu berkaitan dengan politik negara dalam mendidik dan membentuk warganegara yang baik. Pembentukan warganegara yang baik merupakan political choice and pedagogical goal. (Westheimer, dan Kahne, 2014). Setiap negara memliki pilihan politik tergantung pada filosofi, ideology dan tujuan negara itu. Artinya politik pendidikan karakter bagi negara dengan filosofi dan ideology apakah komunis, liberal, dan atau bagi Indonesia dengan Pancasila akan berbeda pada setiap negara. Bentuk, isi, dan praktik pendidikan karakter merupakan konsekuensi dari pilihan politik negara. David Purple, mnegemukakan situasi dilematis praktik pendidikan karakter dihadapkan dengan tuntutan ideology negara. Tidak jarang terjadi situasi dilematis terhadap pilihan nilai yang hendak diajarkan di sekolah. Situasi dilematis itu terjadi ketika pemerintah atau rezim pemerintahan yang berkuasa memasukan nilai-nilai ideologis negara sebagai muatan atau isi pendidikan karakter (Purple, 2014: 145).

Di dalam praksis pendidikan karakter di Indonesia, tidak dapat dipungkiri bahwa pendidikan karakter menjadi instrument politik yang sangat pening dari setiap rezim pemerintahan yang berkuasa. Perubahan kurikulum dan muatan pendidikan karakter yang ada menunjukkan kepentingan politik pemerintahan yang mempengaruhi bentuk dan implementasi pendidikan karakter. Di zaman rezim orde baru berkuasa, Pedoman Penghayatan dan Pengamalan Pancasila (P-4) menjadi instrument pendidikan karakter yang sangat penting ketika itu. Namun ketika di era reformasi, P-4 bahkan dihapuskan dan tidak lagi menjadi instrument pendidikan karakter. Saat ini dan ke depan Pemerintahan Presiden Joko Widodo dan Jusuf Kalla mengusung isyu sentral revolusi mental, dan hal ini tentu berkaitan erat dengan masalah karakter.

Berdasarkan pengalaman empiric tersebut, maka politik pendidikan karakter dapat diartikan sebagai suatu pilihan politik dan tujuan pendidikan yang memberi landasan bagi pengembangan pemikiran dan praktik pendidikan karakter. Pilihan politik pendidikan karakter itu dilandasi oleh pandangan filosif dan idologis negara. Politik pendidikan karakter merupakan instrument dalam nation and character building oleh setiap pemerintahan yang berkuasa.

\section{a) Landasan Filosofis, Konstitusionalitas dan Yuridis Pendidikan Karakter di Indonesia}

Politik pendidikan karakter di Indonesia, secara filosofis dilandaskan pada Pancasila sebagai kristalisasi sistem nilai kehidupan kemasyarakatan, kebangsaan dan kenegaraan. Kelima sila Pancasila memuat nilai-nilai dasar pendidikan karakter. Nilainilai dasar itu menjadi pilar-pilar karakter yang harus dibangun dan dibentuk melalui Pendidikan karakter. Pilar-pilar karakter tersebut adalah (1) pilar religisitas yaitu kualitas kehidupan keberimanan terhadap 
Ketuhanan Yang Maha Esa, (2) pilar humanitas yaitu kaulitas kehidupan kemanusiaan yang harus nyata melalui pengakuan dan oenghormatan terhadap nilainilai kemanusiaan dan suatu tatanan kehdiupan masyarakat yang berbudaya dan beradab, (3) pilar kebangsaan yaitu kualitas nilai-nilai kebangsaan sebagai bagian dari tanggungjawab sebagai warganegara, (4) pilar demokrasi yaitu kualitas kehidupan demokratis yang menjunjung tinggi kedaulatan rakyat, dan (5) pilar keadilan social yaitu kualitas dalam mewujudkan keadilan social bagi seluruh rakyat Indonesia. Nilai-nilai dasar itu memberi landasan etik baik nilai-nilai yang harus diketahui dan dimiliki, pembentukan sikap maupun perilaku etik dan moral. Nilai-nilai dasar Pancasila menjadi muatan utama nilai-nilai yang hendak diajarkan dan dibentuk melalui pendidikan karakter.

Secara konstitusional, Undang-Undang Dasar 1945 memberi landasan bangunan karakter yang hendak dibentuk melalui pendidikan karakter. Bangunan karakter itu adalah ciri kualitas karakter manusia Indonesia baik dalam konteks kehidupan individu, bermasyarakat, berbangsa dan bernegara. Ciri-ciri kualitas karakter tersebut adalah (1) wargaganegara yang cerdas atau civic intelligent, kritis dan dalam memajukan ilmu pengetahuan dan teknologi, warganegara yang berketuhanan Yang Maha Esa, (3) warganegara yang menjunjung tinggi hukum dan pemerintahan, (4) warganegara menjunjung tinggi persatuan dan kesatuan Indonesia dalam wadah Negara Kesatuan Republik Indonesia, (5) warganegara yang memiliki kompetensi keragaman budaya atau cultural diversity competence yang nyata dalam pengakuan dan penghormatan terhadap keragaman budaya baik karena suku, agama, bahasa maupun adat istiadat,
(6) warganegara yang menjunjung tinggi demokrasi dan partisipatif sebagai wujud dari kedaulatan rakyat, (7) warganegara yang bertanggungjawab dalam membela dan mempertahankan negara dan dalam membangun kehidupan bersama atau civic responsibility, dan (8) warganegara yang menjunjung tinggi keadilan dan perjuangan bagi kesejahteraan bersama.

Pedagogical goal pendidikan karakter di Indonesia, secara normative dirumuskan di dalam Undang-undang Nomor 20 Tahun 2003 tentang Sistem Pendidikan nasional. Di dalam Pasal 3 disebutkan sebagai berikut bahwa fungsi Pendidikan nasional adalah mengembangkan kemampuan dan membentuk watak serta peradaban bangsa yang bermartabat dalam rangka mencerdaskan kehidupan bangsa, bertujuan untuk berkembangnya potensi peserta didik agar menjadi manusia yang beriman dan bertakwa kepada Tuhan Yang Maha Esa, berakhlak mulia, sehat, berilmu, cakap, kreatif, mandiri, dan menjadi warga negara yang demokratis serta bertanggung jawab. Rumusan pasal 3 UU No 20 Tahun 2003 tersebut secara eksplisit merumuskan bahwa karakter yang hendak dibentuk melalui pendidikan mencakup karakter-karakter : cerdas, beriman dan bertaqwa kepada Tuhan Yang Maha Esa, berakhlak mulia, kreatif, mandiri, demokratis, dan bertanggungjawab.

Kementerian Pendidikan dan kebudayaan, secara operasional menjabarkan pengembangnan pendidikan karakter ke dalam berbagai kebijakan. Salah satu kebijakan penting adalah menempatkan pendidikan karakter sebagai standar kompetensi lulusan di dalam kurikulumkurikulum sekolah termasuk di dalam Kurikulum 2013. Terdapat dua dari empat komperensi inti yang terkait dengan pendidikan karakter yaitu kompetensi 
spiritual, dan kompetensi sosial yaitu sebagai pribadi yang beriman, berakhlak mulia, percaya diri, dan bertanggung jawab dalam berinteraksi secara efektif dengan lingkungan sosial, alam sekitar, serta dunia dan peradabannya. Sikap dan prilaku yang hendak dibentuk melalui ciri karakter tersebut diliha dalam ciri-ciri sikap dan perilaku seperti menerima dan menjalankan ajaran agama, jujur, disiplin, tanggung jawab, santun, peduli, percaya diri, bersikap adil, mandiri, dan toleran dimulai dari kehidupan keluarga, lingkungan bermain, sekolah dan lingkungan yang lebih luas.

Kementerian

Koordinator

Kesejahteraan Rakyat pada tahun 2010 juga telah merumuskan dasar-dasar dan kerangka kebijakan pendidikan karakter melalui Grand Design Pendidikan Karakter yang digambarkan sebagai berikut (gambar 3). Kerangka kebijakan pengembangan pendidikan karakter tersebut menggambarkan konteks dan permasalahan, mutu nilai yang menjadi ciri karakter serta pendekatan dan lingkup tanggungjawab terhadap pelaksanaan pendidikan karakter. Keluarga, pemerintah, sekolah serta berbagai lembaga-lembaga sosial, agama, ataupun politik mempunyai tanggungjawab bersama atas penyelenggaran pendidikan karakter. Artinya pendidikan karakter tidak hanya menjadi tanggungjawab sekolah tetapi juga menjadi tanggungjawab bersama. Kerangka kebijakan tersebut menunjukkan politik negara dan pemerintah Indonesia yang menggambarkan posisi pendidikan karakter sebagai pilar penting dalam pendidikan nasional dalam pembangunan karakter bangsa.

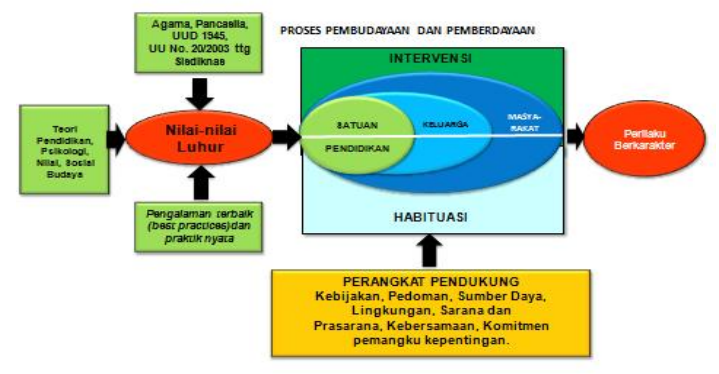

Gambar 3. Grand Design Pengembangan

Pendidikan Karakter (Winataputra, 2010).

\section{b) Perspektif Historis Pendidikan Karakter di Indonesia}

Pemikiran mengenai pendidikan karakter di Indonesia sudah tercermin dalam pemikiran tokoh-tokoh pendidikan nasional seperti Ki Hadjar Dewantara. Terdapat dua unsur penting dalam pemikiran Ki Hadjar Dewantara tentang pendidikan yaitu pendidikan sebagai proses humanisasi dan homonisasi. Pendidikan sebagai proses humanisasi menempatkan pembentukan karakter unsur penting dalam pendidikan, sebab di dalam proses humanisasi itu karakter anak dibentuk sehingga terjadi proses pemanusiaan manusia yaitu menjadi manusia yang berkarakter. The founding fathers seperti Ir. Soekarno Presiden pertama Indonesia, menyadari bahwa persoalan penting bangsa Indonesia adalah nation and character building. Pemikiran-pemikiran kedua tokoh tersebut merupakan pemikiran yang futuristik mengenai persoalan penting bangsa Indonesia, karena hingga saat ini dan ke depan Indonesia masih menghadapi persoalan pembentukan karakter bangsa.

Terdapat isyu-isyu penting dalam pembangunan karakter yang mempengaruhi kebijakan politik pendidikan karakter di Indonesia sejak kemerdekaan hingga saat ini dan juga ke depan. Di awal kemerdekaan isyu pembangunan karakter yang utama ialah pembentukan pemahaman, sikap dan perilaku sebagai warganegara yang merdeka dan tanggungjawab untuk mempertahankan kemerdekaan dan dalam membangun 
pemerintahan sebagai bangsa yang merdeka dan berdaulat. Hingga saat ini berkembang isyu-isyu kontemporer yang terkait dengan hubungan negara atau pemerintah dengan warganegara, demokratisasi, perlindungan hak-hak asasi manusia, dan tantangan yang muncul dalam konteks kehidupan global. Oleh sebab itu, politik pendidikan karakter dilihat sebagai salah satu instrument dalam menjawab berbagai isyu-isyu yang berkembang.

Implementasi politik pendidikan karakter di Indonesia pertama bersifat separated yaitu diberikan secara terpisah dalam mata pelajaran tersendiri. Di awal kemerdekaan pada Kurikulum 1946 pembentukan sikap kewarganegaraan diberikan melalui mata pelajaran Pengetahuan Umum yang berisi tentang pemerintahan. Kemudian di dalam perkembangannya mengalami perubahan baik nama mata pelajaran maupun substansi isi. Oleh sebab itu di dalam kurikulum sekolah terdapat mata pelajaran berbeda tetapi melaksanakan fungsi pendidikan karakter seperti Pedidikan Agama, Pendidikan Budi Pekerti, Civics, Pendidikan Moral Pancasila, Pendidikan Kewaragenagraan, Pendidikan Pancasila dan Kewarganegaraan, dan juga Pendidikan Sejarah Perjuangan Bangsa (PSPB). Pendidikan karakter yang termuat dalam berbagai mata pelajaran tersebut, mewarnai berbagai kurikulum yang pernah berlaku yaitu Kurikulum 1947 yan gmulai berlaku tahun 1950, Kurikulum 1952, Kurikulum 1964, Kurikulum 1968, Kurikulum 1975, Kurikulum 1984, Kurikulum 1994, Kurikulum 2004 yang dikemnal dengan Kurikulum Berbasis Kompetens atau KBK, dan Kurikulum 2006 dikenal dengan Kurikulum Tingkat Satuan Pendidikan (KTSP).
Kedua, perubahan mendasar terjadi pada kurikulum 2013, pendekatan pendidikan karakter dilakukan secara integrated dimana semua mata pelajaran sekolah mempunyai tanggungjawab dalam pembentukan dua kompetensi inti yaitu sikap sosial dan sikap spiritual. Sekalipun demikian secara terpisah diberikan pula melalui mata pelajaran seperti Pendidikan Agama dan Pendidikan Kewarganegaraan. Melalui berbagai mata peajaran tersebut, ditanamkan nilai-nilai yang harus menjadi muatan pendidikan karakter. Nilai-nilai karakter tersebut adalah sebagai berikut: (1) menerima dan menjalankan ajaran agama yang dianutnya, (2) sikap dan perilaku jujur, (3) disiplin, (4) tanggung jawab, (5) santun, (6) peduli termasuk gotong royong, toleran, dan damai, percaya diri, (8) berinteraksi secara efektif dengan lingkungan, (9) partisipatif dalam memecahkan masalah bersama, dan (10) responsive dan proaktif. (Pasandaran, 2013:10).

Ketiga, arus kuat politik pendidikan karakter sangat nampak pada kebijakan dalam benmtuk ketetapan MPR tentang Pedoman Penghayatan dan Pengamalan Pancasila atau lebih dikenal dengan P4. Ide utama P4 adalah menjadikan nilai-nilai Pancasila dihayati dan diamalkan oleh semua penyelenggara negara, tokoh dan pimpinan baik lembaga-lembaga formal maupun noin formal politik, pemerintahan, dan kemasyarakatan. Nilai-nilai Pancasila diharapkan tidak saja dihayati tetapi lebih jauh dari itu diamalkan. Sekalipun ide utama P4 tersebut sangat baik, tetapi mengalami pergeseran bahkan menjadi instrument politik pemerintah yang bersifat indoktrinatif sehingga mengakibatkan terjadinya kategorisasi Pancasilais bagi yang mengikuti doktrin P4 dan non Pancasilais bagi yang tidak mengikuti doktrin. Di era reformasi 
terjadi perubahan yang sangat mendasar yaitu dicabutnya ketetapan MPR tentang P4 tersebut. Kebijakan dan perubahan tersebut berimplikasi pada politik pendidikan karakter yang tercermin baik di dalam Kurikulum 2004, Kurikulum 2006, maupun Kurikulum 2013.

\section{Simpulan dan Rekomendasi}

1. Pendidikan karaktrer mempunyai peranan penting dalam rangka nation and character building. Peranan itu dimulai dari dalam keluarga, lembaga pendidikan, lembaga kemasyarakat, keagamaan, politik dan pemerintahan, sehingga pendidikan karakter menjadi tanggungjawab bersama.

2. Politik pendidikan karakter adalah suatu pilihan politik dan tujuan pendidikan yang memberi landasan bagi pengembangan pemikiran dan praktik pendidikan karakter. Pilihan politik pendidikan karakter itu dilandasi oleh pandangan filosofis dan idologis negara.

3. Politik pendidikan karakter di Indonesia memiliki landasan religisitas, humanitas, kebangsaan, demokrasi, dan keadilan yang berakar pada sistem nilai budaya dan kemasyarakatan, dan yang terumus di dalam Pancasila, Undang-Undang Dasar 1945 sebagai landasan filosofis, etik, dan konstitusional.

4. Praksis pendidikan karakter di Indonesia sangat dipengaruhi oleh politik negara dan pemerintah, dan yang dikembangkan melalui keragaman mata pelajaran kurikulum sekolah sebagai lembaga pendidikan formal. Politik pendidikan karakter itu dipengaruhi oleh isu-isu temporer setiap rezim pemerintahan baik di awal kemerdekaan, era orde lama, orde baru, reformasi, dan isu-isu termporer saat ini
5. Diperlukan penguatan pembentukan pilrapilar karakter yang terkandung di dalam landasan filosofis dan konstitusional. Penguatan itu dapat dilakukan melalui revitalisasi praksis pendidikan karakter baik yang menyangkut isu-isu filosofis, konstitusional maupun temporer.

6. Keterlibatan semua pihak baik lembaga pendidikan, lembaga keluarga, pemerintahan, politik, kemasyarakatan, dan keagamaan sangat diperlukan sebagai wujud dari tanggungjawab bersama. Pendidikan karakter harus menjadi sebuah gerakan nasional dengan mensinergikan semua komponen baik kelembagaan maupun individual.

\section{Daftar Pustaka}

Winataputra, Udin Saripudin. 2010. Implementasi kebijakan Nasional Pembangunan Karakter Bangsa melalui Pendidikan Karakter, http://kisyani.files.wordpress.com

Corruption Perception Index. https://www.transparency.org/cpi2014

Lickona, Thomas, 1992, Educating for Character, A Bantam Books New York.

Stedje, Lauree Beth, 2010, Nuts and Bolts of Character Education, http://www.characterfirst.com/

Berkowitz, Marvin and Howard Robert, Esther Schaeffer, 2004, Politcs of Character Education, Educational Policy, Vol. 18 No. 1, January and March 2004, p. 189. http://www.fresnostate.edu/, Diakses 20 Oktober 2014).

Kahne Joseph and Westheimer, Joel., Educating the "Good" Citizen: Political Choices and Pedagogical Goals, 
http://www.mills.edu/academics/facult y/educ/jkahne, (diakses 20 Oktober 2014).

Purple, David, The politic of Character education, http://www.bamaed.ua.edu/ (diakses 15 September 2014).

Kementerian Koordinator kesejahteraan Sosial, RI, di dalam Udin Saripudin Winataputra, 2010, Implementasi Kebijakan Nasional Pembangunan Karakter Bangsa melalui Pendidikan Karakter, http://kisyani.files.wordpress.com.

Pasandaran, Sjamsi, 2012, Pengembangan Pendidikan Karakter dalam Perspektif Kurikulum 2013, Materi Seminar Nasional HISPISI, Manado, Nopember 2013. 